\title{
GCU
}

Glasgow Caledonian

University

University for the Common Good

\section{The new merger: combining third sector and market-based approaches to tackling inequalities}

Roy, Michael; Hill O'Connor, Clementine; McHugh, Neil Anthony; Biosca, Olga; Donaldson, Cam

Published in:

Social Business

DOI:

$10.1362 / 204440815 \times 14267607784848$

Publication date:

2015

Document Version

Author accepted manuscript

Link to publication in ResearchOnline

Citation for published version (Harvard):

Roy, M, Hill O'Connor, C, McHugh, NA, Biosca, O \& Donaldson, C 2015, 'The new merger: combining third sector and market-based approaches to tackling inequalities', Social Business, vol. 5, no. 1, pp. 47-60. https://doi.org/10.1362/204440815X14267607784848

\section{General rights}

Copyright and moral rights for the publications made accessible in the public portal are retained by the authors and/or other copyright owners and it is a condition of accessing publications that users recognise and abide by the legal requirements associated with these rights.

Take down policy

If you believe that this document breaches copyright please view our takedown policy at https://edshare.gcu.ac.uk/id/eprint/5179 for details of how to contact us. 


\section{The New Merger: combining Third Sector and market-}

\section{based approaches to tackling inequalities}

Michael J. Roy*, Clementine Hill O’Connor, Neil McHugh, Olga Biosca and

Cam Donaldson

Yunus Centre for Social Business and Health and Glasgow School for Business and Society, Glasgow Caledonian University, Glasgow, UK

${ }^{*}$ Corresponding Author

AUTHOR'S PRE-PUBLICATION VERSION 


\begin{abstract}
In this paper we discuss the challenge posed by growing inequalities, specifically health inequalities, which have grown increasingly wider in recent decades. Rather than arguing for a wholesale return to state intervention to curb the worst excesses of the market, we put forward a less-obvious potential solution, arguing for a greater role and greater recognition - for the 'social economy': the part of the Third or non-profit sector concerned with trading in the market, rather than relying upon public funds or charitable donations to stay in business. We present three examples of such organisations, drawn from the UK, and discuss how doing business in such a way presents obvious benefits for, but challenges to, existing thinking, particularly in relation to how 'success' should be measured.
\end{abstract}

Key words: inequality, social enterprise, microcredit, self reliance 


\section{Background}

All levels of UK society have experienced substantial improvements in both economic and social life since the end of the Second World War. Notable amongst these has been the significant increase in average life expectancy (Shaw, Dorling, \& Smith, 2005). However, not everyone has experienced these improvements equally: accompanying the trend of ever widening income inequality, particularly since the end of the 1970s, health inequalities - the avoidable and unfair differences in mortality and morbidity between the richest and poorest groups in society - have steadily increased. This occurrence leads us to consider that there is a limit to the impact that traditional forprofit enterprise and public sector provision can have on reducing poverty and health inequality, and to ask whether alternative or supplementary models, perhaps from the 'third sector' - the intermediate space between private business and the state (Defourny, Hulgård, \& Pestoff, 2014; Evers \& Laville, 2004) may have potential in this regard.

\section{Failed markets, failing governments? Poverty and health}

\section{inequalities}

It has long been postulated that encouraging enterprise and entrepreneurship through neo-liberal economic policies would spur economic growth and reduce poverty, with benefits trickling-down to all levels of society. However, the neoliberal record has been less than impressive in this area (Hall \& Midgely, 2004; Mooney, 2012). The UK, despite being labelled an 'advanced' economy, suffers from obstinate and ever-widening inequalities, with the resulting consequences impacting disproportionately upon the most vulnerable in society. In the city of Glasgow, where the authors are based, one 
quarter of Glasgow's citizens are defined as deprived, with life expectancy gaps of up to 28 years between richest and poorest (Commission on Social Determinants of Health, 2008). Many public health experts would claim that a key requirement in narrowing this gap would be to act on the material circumstances of the most vulnerable members of society (Marmot \& Wilkinson, 2006; Marmot, 2010). Since health inequalities are the preventable and unfair differences in health status between social groups, populations and individuals (Whitehead, Dahlgren, \& Gilson, 2001) they are seen to be no less than the 'scandal of our times' (Dorling, 2013); they represent the starkest and most profound inequalities given that "the right to life itself is at stake" (McCartney, Collins, \& Mackenzie, 2013, p. 222).

So if it is low income, societal exclusion and hopelessness that kill people, there is a need to work on the 'causes of the causes' or 'fundamental causes' (Phelan, Link, DiezRoux, Kawachi, \& Levin, 2004) of such factors, perhaps through employing more holistic community-based initiatives. But many mainstream public health initiatives aim to impact upon individual risk factors such as diet or exercise. If, instead, one imagines, as the American Heart Association were asked to do at an address in the 1970s, a rapidly flowing river where people are constantly rescuing drowning victims, it would make sense to look upstream to see what is causing people to fall into the river (McKinlay, 1974, 1979). Looking 'upstream' in this case could mean employing initiatives that mobilise and build upon existing collective resources or 'assets' (Chief Medical Officer for Scotland, 2011) which individual and communities already have at their disposal to promote health and well-being, changing the conditions that lead to adverse health behaviours (Kelly, McDaid, Ludbrook, \& Powell, 2005) rather than simply focusing upon their deficiencies (Roy, Donaldson, Baker, \& Kay, 2013). Such approaches could be seen 
to be consistent with the call for a needed 'fifth wave' of public health (Hanlon, Carlisle, Hannah, Reilly, \& Lyon, 2011): the 'first wave' being associated with large scale public works and other developments arising from social responses to profound disruptions following the Industrial Revolution; the 'second wave' saw the emergence of medicine as science; the 'third wave' of public health involved the redesign of social institutions during the 20th Century which gave birth to the welfare state; while the 'fourth wave' has been dominated by efforts to combat disease risk factors and the emergence of systems thinking in public health.

\section{The call for new economic thinking}

The traditional calls to counterbalance the excesses of the market are for increased Government intervention or (particularly more recently) enhanced Corporate Social Responsibility (CSR). However, they each have their limits. As well as the failures referred to above, the reality for most countries in the developed world since the great financial crisis of 2008 is that public finding has been dramatically cut, curbing the ability of the state to intervene. This has precipitated calls for new economic thinking to address the most pressing and obstinate social challenges (Keen, 2011; Stiglitz, 2010). Despite becoming more mainstream in recent years, CSR, too, has its limits and its critics (see, for instance, Rieto-Carrón, Lund-Thomsen, Chan, Muro, \& Bhushan, 2006). And let us not forget that Milton Friedman famously argued that the social responsibility of business is to increase its profits' (Friedman, 1970): in many countries company law remains very clear in respect of the fiduciary duties of directors thus forprofit enterprises engaging in CSR have to be doing so because it is consistent with furthering the profit/shareholder return imperatives of the company. It would be a dereliction of duty, backed up by weight of the law, for it to be otherwise (Bakan, 2005). 
One idea that has come increasingly to the fore in recent decades, however, relates to the potential of the 'social economy' (Amin, 2009; Mendell, 2009) or the part of the Third or non-profit sector concerned with trading, rather relying (wholly) upon public funds or charitable/philanthropic donations (Dees, 1998; Eikenberry and Kluver, 2004; Pearce, 2003). While the importance of a vibrant civil society to reducing health and well-being is acknowledged in public health literature (see, for example, Blas et al., 2008; O'Mara-Eves et al., 2013) the impact of the trading segment of the third sector on health and well-being is not as well developed (Roy, Donaldson, Baker, \& Kerr, 2014).

The types of organisations presented briefly here 'go with the grain' of the market, but the principal aim of each is not to maximise profits for owners or shareholders, but to maximise social impact and address the needs and circumstances of the most vulnerable and marginalised members of society. Such organisations are able to draw upon a wider 'mix' of resources (Gardin, 2006) than traditional state provision or wellmeaning but 'patronizing' (Dees, 1998) charities - it is claimed - can do by themselves. The entities presented embody - in full or in part - the implementation of businessbased practices: microfinance, 'self-reliant groups' and social enterprise. Each will be described in turn. But as well as thinking differently about business, our ideas also offer a completely different way of thinking about the role of the third sector. We are really at the beginning of this theoretical and conceptual development, but have recently received a substantial grant from the UK's Medical Research and the Economic and Social Research Councils to develop our conceptual thinking further and test our theories through empirical work with third sector partners (Glasgow Caledonian University, 2013). Our hypothesis at this stage is that such entities can impact upon health through more direct routes, such as income enhancement, but also in less 
obvious ways, such as increased confidence and purposefulness, and perhaps further back in the chain of causality to address some of the structural forces that can mitigate against, or reinforce, social vulnerability at the local level. We know about the connection between social capital and health (Ferguson, 2006; Uphoff, Pickett, Cabieses, Small, \& Wright, 2013), and the importance of 'capabilities' (Nussbaum, 2011; Nussbaum \& Sen, 1993; Sen, 1985, 2008) to human development and well-being, which has received significant high profile attention in recent decades, including, in the past, by Yunus (1998, p. 48):

"poverty is caused by our inadequate understanding of human capabilities and by our failure to create enabling theoretical frameworks, concepts, institutions and policies to support those capabilities."

The impact of third sector organisations could be examined using such available theoretical 'lenses'. The mechanisms of action leading from the social mission, to trading in the market, through to improvements in health and well-being, and the various 'pathways to impact' in between could, we argue, be better conceptualised and better understood. Furthermore, we postulate that such pathways to health and well-being can be facilitated by any of the organisational types we are about to describe regardless of whether they explicitly mention 'health' in their mission statement, whether they trade in health products, or even operate (perhaps on a contractual basis with the state) in health 'quasi-markets' (Degavre \& Nyssens, 2012; Mays, Mulligan, \& Goodwin, 2000). By definition, most third sector organisations aim to act on some aspect of social vulnerability and, therefore, very likely on one or more upstream 'social determinants of health' (Donaldson et al., 2011; Marmot \& Wilkinson, 2006; Roy et al., 2013). 


\section{Microcredit for entrepreneurship}

Microcredit is the issuance of small, collateral-free loans typically extended to those excluded from mainstream financial institutions (McHugh, Gillespie, Loew, \& Donaldson, 2014). These loans are used for either enterprise or personal purposes. Microcredit itself is a component of the wider term microfinance which encompasses other financial services such as savings or insurance; institutions offering these products are known as Microfinance Institutions (MFIs). Although MFIs are now widespread, particularly in developing countries, the microcredit industry emerged from the need to combat financial market inefficiencies that tend to discriminate against the poorest members of society. These inefficiencies are generally caused by information asymmetries and agency problems (Stiglitz, 1990).

The microcredit sector circumvented these problems by designing innovative credit contracts characterised by group lending, targeting women, progressive lending and flexible, public and regular repayments. This enabled MFIs to transform the 'unbankable' into the 'bankable poor' (Weber, 2004). Such success, in reaching those previously excluded, has led to MFIs being used increasingly in more advanced economies. In Scotland, and the UK, MFIs concentrate principally on areas suffering from 'financial desertification' (Bank of England, 2000) where traditional financial institutions have vacated the market due to the cost and risk of operation. While various company and ownership structures are utilised by MFIs in developing countries, ranging from shareholder firms to cooperatives and non-governmental organizations (NGOs), in advanced economies MFIs mainly have a not-for-profit or charitable status and operate as social businesses. 
These operating models are in line with the aim of mitigating financial and social exclusion and having a positive impact upon the lives of individuals. MFIs in advanced economies are conceived as socially-oriented community initiatives that act as a 'bottom-up' tool for development. Their ownership and governance structures are often aimed at empowering, engaging and involving clients in the decision making, management and control of the financial institutions.

\section{Self-Reliant Groups}

Self-Reliant Groups (SRGs) are the result of a project originally initiated by the Church of Scotland which are now supported by an independent charity called 'WEvolution'. This project seeks to offer an alternative model of socio-economic development for women in deprived areas of the country (Hill O'Connor, 2013; Roy, McHugh, \& Hill O'Connor, 2014). The SRG model is influenced by the Self Help Groups (SHGs) model in India, which has been successful in bringing women together around the practice of savings and loans which have developed further to serve as a platform for wider social (Swain \& Wallentin, 2009).

SHGs utilise group lending systems, and then link to a bank to access microcredit. This enables women to start, or scale up businesses. In a number of cases the increase in income has given women the economic power to increase their ability to address social problems in their communities (Tesoriero, 2006). SHGs have effectively challenged issues around access to medical care, agricultural management, education and political participation (Khatibi and Indira, 2011; Mohindra et al, 2008).

The groups formed in Scotland have been renamed Self-Reliant Groups (SRGs) but retain much of the ethos of SHGs. Women from similar socio-economic backgrounds 
have organised themselves, facilitated by WEvolution, into groups of 5-10, meeting and saving small amounts of money on a weekly basis. From here they have developed new skills, built group confidence and started collective micro-enterprises. Capital for the enterprises has come from a combination of group savings and microcredit provided by Church funds and administered through WEvolution.

Research to date shows that WEvolution SRGs have provided a valuable space for women to be productive and take part in what they consider to be meaningful activity and SRG members feel this has contributed to their improved levels of confidence (Hill O'Connor, 2013). Development of bridging, bonding and linking social capital (Szreter \& Woolcock, 2004) has also been an important part of this process as women form trusting relationships not only with their close community, but also with individuals they would not interact with in their lives outside of the SRG. Beyond improved levels of confidence and trust SRGs are beginning to have an impact on the economic circumstances of those involved. Internal loan functions of the SRG provide a 'safety net' for individuals in times of crisis and the profits from their small enterprises have been disbursed in the form of supermarket vouchers in the lead up to Christmas when SRG members appear to feel the most financial stress. Currently, social capital appears to be the primary process through which improved well-being is being achieved, however future research will explore other processes such as economic factors, employment status and business development.

\section{Social Enterprise}

Focus upon 'social enterprise', and the closely related terms 'social entrepreneur' and 'social entrepreneurship', has significantly increased in recent years (Defourny, 2009) but all of these terms remain highly contested and politically charged (see Teasdale, 
2011). In the UK, unlike other countries around Europe, there is no legally accepted definition of a social enterprise, which has traditions going back many centuries (Mayo, Sattar, Conaty, \& McGeehan, 2001; Spear, 2001). However, a UK government definition developed around the turn of the millennium still retains popularity:

"a business with primarily social objectives whose surpluses are principally reinvested for that purpose in the business or in the community, rather than being driven by the need to maximise profit for shareholders and owners" (Department of Trade and Industry, 2002, p. 14).

Recently mainstream private industry, encouraged by the UK's current Conservative/Liberal Democrat coalition Government, has engaged in stretching the concept, arguably as a 'smokescreen' for privatisation of public services (Millar, 2012; Roy et al., 2013), to the extent that the term 'social enterprise' is at risk of becoming meaningless. In reaction to this threat, an influential group in Scotland, a country that it is claimed - has the 'most supportive environment in the world for social enterprise' (Ainsworth, 2012; Roy, McHugh, Huckfield, Kay, \& Donaldson, 2014) has come up with five essential elements or criteria as listed in Table 1 (SENSCOT, 2010, 2013).

These criteria roughly coincide with Yunus's Principles for Social Business (Yunus, 2009a, 2009b), whose work which has inspired many social entrepreneurs around the globe. Hence, it is not problematic in Scotland or, indeed, in many other parts of Europe (Esposito, 2013), to use the terms 'social enterprise' and 'social business' interchangeably. Indeed, this is done quite frequently by the European Commission (see, for instance, (European Commission, 2011a, 2011b, 2014). 


\section{Table 1: What is a social enterprise? The SENSCOT definition}

1. A Social Enterprise (SE) is a business trading in the marketplace - selling goods and services - but whose primary objective is to achieve social and/or environmental benefit.

2. Regardless of its legal form, the constitution of a SE will include the requirement that profits are reinvested in the business or in the beneficiary community - and not distributed to owners/shareholders/investors.

3. The constitution will always require that on dissolution, the assets of the SE are reinvested in another organisation with similar aims and objectives.

(Taken together Criteria 2 and 3 are referred to as the 'asset lock' - the defining characteristic of a SE - which distinguishes it from the private sector.)

4. SEs are different from those charities and voluntary organisations which do not aspire to financial independence through trading.

5. SEs are distinct from the public sector and cannot be the subsidiary of a public body.

It is recognised, however, that different conceptualizations of social enterprise exist throughout the world (see, for example, (Kerlin, 2006, 2009, 2013; Defourny \& Kim, 2011; Defourny \& Nyssens, 2010, 2012; Young \& Lecy, 2013) and so this will be more of an issue in some places than others. The point is, however, that social enterprises - at least as they are understood in Scotland and many parts of mainland Europe - use trading in the market as a means to an end (fulfilment of a social mission) rather than for the accumulation of wealth for investors. Of course they are required to be profitable in order to stay in business, but this is not their purpose.

\section{The challenge of evaluation}

As the approaches outlined operate differently to more conventional ideas of what a business is, a key question to be answered is: what is the added value of such entities for addressing social ills? 
Conventionally, one might think to evaluate such initiatives on the basis of economic activity generated - measured through some sort of monetary return and employment created - or perhaps through the lens of stakeholder theory (Freeman, 1984), which seeks to address the moral and ethical dimensions of organisational management. But these ignore the issue of whether there is something in the very essence of third sector business-oriented ventures which not only results in improved performance on the basis of 'hard' economic measures, but also have value in and of themselves. These aspects might be encompassed by the notion of encouraging self-help in a community environment, thus providing more meaning to people's lives as well as improved social networks and connectedness. These in turn might further boost health and well-being beyond what might 'simply' be achieved by income enhancement (Milton et al., 2011; Wallerstein, 2006). This could create a complex relationship with government, requiring regulation, to encourage expansion of genuine social economy activity (howsoever defined), and even a positive case for subsidy, if such activities prove to enhance health and well-being to greater degrees than other more-conventional uses of such resources.

To undertake the research required to generate such evidence, such approaches have to be evaluated distinctly from traditional management theory/business school conventions that include simply applying established strategic approaches from the commercial world to social problems (Nicholls \& Young, 2008). A more nuanced approach is required, sensitive to the politics of social problems, employing researchers from a range of disciplines, including economists, historians, anthropologists and sociologists, to develop new conceptual models of how engagement with businessoriented organisations in the social economy might translate into improvements in 
health and well-being. Certain disciplines, such as political economy and sociology, provide many more researchers who adopt a critical (in the 'emancipatory' sense) stance than the business school. But, to this point, business-oriented academics and practitioners have had a dominant presence in social entrepreneurship and social enterprise (and, indeed social business) research. This has led, it could be argued, to the success of such initiatives being judged on their ability to address entrenched market (or state) failures (or symptoms of problems) rather than their ability to challenge political and/or economic structures - which, it is commonly argued, are commonly at the root; the fundamental 'upstream' causes of problems.

By extension, this would necessitate employing alternative evaluation methodologies and introduces considerable complexities in identifying causation. Tracking individual participants over time, for instance, often involves employing participatory research approaches and this is certainly the case with the current ongoing evaluation of the WEvolution women and their SRGs, which relies upon the skills of an anthropologist. Then there is the question of whether social enterprises and MFIs could be persuaded to participate in more-longitudinal comparative evaluations of the sort that might be more recognisable in medical research settings: employing mixed (qualitative and quantitative) methods and adding disciplines of statistics, public health and specific content-based expertise depending on the particular social mission (such as the prevention of homelessness, or the prevention of social isolation in older age) of the organisations evaluated.

\section{Conclusion}

In this paper we have explored the idea that business-oriented initiatives from the third sector aim to act upon the collective resources (or 'assets') which individuals and 
communities have at their disposal to protect against negative health outcomes and promote health and well-being. We have highlighted how such alternative business models might challenge existing perceptions on profit maximisation, distribution of surpluses to shareholders, and governance. But we have also focused on mechanisms that are decidedly 'bottom up' in nature: some of the social entrepreneurship literature, particularly as taught in business schools, too often presents the poor as potential consumers waiting to be exploited. Too frequently such literature promotes the acceleration of entrepreneurial approaches and innovative solutions of large NGOs and Foundations, or the maverick 'hero' social entrepreneur as holding the solution to the world's most pressing social issues. But, look harder, and it is found that such examples often aim to address specific symptoms of much deeper underlying problems. There are significant risks in commodifying social processes, as something that the utopian model of a laissez-faire market can somehow address on its own, and can lead to circular arguments that solutions to problems often caused by the market also lie in the market! Many of the most pressing problems faced by communities will require a very specific, localised solution, and often will require partnership working with the state, codesigned or co-produced (Brandsen \& Pestoff, 2006; Pestoff, 2013) to mobilise and better target resources to those most in need, in a highly context-specific manner. This, however, poses challenges to those who seek to achieve 'scale' as quickly as possible; working locally to address social issues often takes hard work, patience, is often not glamorous, and requires a thorough appreciation of local context.

Furthermore, to begin to tackle the 'causes of causes' of (up to now) intractable social problems in a sustainable and lasting way, history reminds us that it is most often achieved as a bottom up, collective, endeavour. Specific approaches that 'go with the 
grain' of the market to target the most marginalised and vulnerable individuals in society allows for different - potentially empowering and emancipatory - ownership and management structures. As well as generating economic outcomes, our hypothesis is that, through engendering self-help in more connected settings, appreciating the challenges posed by agency and structure, such approaches could well boost health and well-being too. 


\section{References}

Ainsworth, D. (2012, March 28). Scotland's Social Enterprises Seem to Have It Made. Third Sector. Retrieved from http://thirdsector.thirdsector.co.uk/2012/03/28/scotlandssocial-enterprises-seem-to-have-it-made/

Amin, A. (Ed.). (2009). The Social Economy: International Perspectives on Economic Solidarity. London: Zed Books.

Bakan, J. (2005). The Corporation: The Pathological Pursuit of Profit and Power. New York: Free Press.

Bank of England. (2000). Finance for Small Businesses in Deprived Communities. London: Bank of England.

Blas, E., Gilson, L., Kelly, M. P., Labonté, R., Lapitan, J., Muntaner, C., ... Sen, G. (2008). Addressing Social Determinants of Health Inequities: What Can the State and Civil Society Do? The Lancet, 372(9650), 1684-1689.

Brandsen, T., \& Pestoff, V. (2006). Co-Production, the Third Sector and the Delivery of Public Services. Public Management Review, 8(4), 493-501.

Chief Medical Officer for Scotland. (2011). Health in Scotland 2010: Assets for Health. Edinburgh: Scottish Government. Retrieved from http://www.scotland.gov.uk/Resource/Doc/365208/0124172.pdf

Commission on Social Determinants of Health. (2008). Closing the Gap in a Generation: Health Equity Through Action on the Social Determinants of Health. Geneva: World Health Organization.

Dees, J. G. (1998). Enterprising Nonprofits. Harvard Business Review, 76(1), 54-67.

Defourny, J. (2009). Foreword. In J. A. Kerlin (Ed.), Social Enterprise: A Global Comparison (pp. xi-xviii). Lebanon, NH: University Press of New England. 
Defourny, J., Hulgård, L., \& Pestoff, V. (Eds.). (2014). Social Enterprise and the Third Sector: Changing European Landscapes in a Comparative Perspective. Abingdon, Oxon: Routledge.

Defourny, J., \& Kim, S.-Y. (2011). Emerging Models of Social Enterprise in Eastern Asia: A CrossCountry Analysis. Social Enterprise Journal, 7(1), 86-111. doi:10.1108/17508611111130176

Defourny, J., \& Nyssens, M. (2010). Conceptions of Social Enterprise and Social Entrepreneurship in Europe and the United States: Convergences and Divergences. Journal of Social Entrepreneurship, 1(1), 32-53.

Defourny, J., \& Nyssens, M. (2012). Conceptions of Social Enterprise in Europe: A Comparative Perspective with the United States. In B. Gidron \& Y. Hasenfeld (Eds.), Social Enterprises: An Organizational Perspective (pp. 71-90). Basingstoke, Hampshire: Palgrave Macmillan.

Degavre, F., \& Nyssens, M. (2012). Care Regimes on the Move: Comparing Home Care for Dependent Older People in Belgium, England, Germany and Italy. Centre Interdisciplinaire de Recherche Travail, Etat et Société, Université Catholique de Louvain. Retrieved from http://www.uclouvain.be/417745.html

Department of Trade and Industry. (2002). Social Enterprise: A Strategy for Success. London: DTI.

Donaldson, C., Baker, R., Cheater, F., Gillespie, M., McHugh, N., \& Sinclair, S. (2011). Social Business, Health and Well-Being. Social Business, 1(1), 17-35.

Dorling, D. (2013). Unequal Health: The Scandal of Our Times. Bristol: Policy Press.

Eikenberry, A. M., \& Kluver, J. D. (2004). The Marketization of the Nonprofit Sector: Civil Society at Risk? Public Administration Review, 64(2), 132-140. 
Esposito, R. T. (2013). The Social Enterprise Revolution in Corporate Law: A Primer on Emerging Corporate Entities in Europe and the United States and the Case for the Benefit Corporation. William \& Mary Business Law Review, 4, 639-767.

European Commission. (2011a). Empowering People, Driving Change: Social Innovation in the European Union. Luxembourg: Publications Office of the European Union. Retrieved from http://ec.europa.eu/bepa/pdf/publications_pdf/social_innovation.pdf

European Commission. (2011b). Social Business Initiative. Retrieved January 21, 2012, from http://ec.europa.eu/internal_market/social_business/index_en.htm

European Commission. (2014). Strasbourg Declaration: Empowering Social Entrepreneurs for Innovation, Inclusive Growth and Jobs. Strasbourg: European Commission. Retrieved from http://ec.europa.eu/internal_market/conferences/2014/0116-socialentrepreneurs/docs/strasbourg-declaration_en.pdf

Evers, A., \& Laville, J.-L. (2004). The Third Sector in Europe. Cheltenham: Edward Elgar Publishing.

Ferguson, K. M. (2006). Social Capital and Children's Wellbeing: A Critical Synthesis of the International Social Capital Literature. International Journal of Social Welfare, 15(1), 218.

Freeman, R. E. (1984). Strategic Management: A Stakeholder Approach. Boston: Pitman.

Friedman, M. (1970, September 13). The Social Responsibility of Business is to Increase its Profits. The New York Times Magazine. Retrieved from http://www.colorado.edu/studentgroups/libertarians/issues/friedman-soc-respbusiness.html

Gardin, L. (2006). A Variety of Resource Mixes Inside Social Enterprises. In M. Nyssens (Ed.), Social Enterprise: At the Crossroads of Market, Public Policies and Civil Society. (pp. 111136). Abingdon: Routledge. 
Glasgow Caledonian University. (2013, November 29). £2m Study Will Examine Impact of Social Enterprise on Health in Scotland. Retrieved December 9, 2013, from http://www.gcu.ac.uk/yunuscentre/newsevents/news/article.php?id=68021

Hall, A. L., \& Midgely, J. (2004). Social Policy for Development. Thousand Oaks, Calif.: SAGE.

Hanlon, P., Carlisle, S., Hannah, M., Reilly, D., \& Lyon, A. (2011). Making the Case for a "Fifth Wave" in Public Health. Public Health, 125(1), 30-36.

Hill O'Connor, C. (2013). The Role of Self Reliant Groups (SRGs) in Improving Individual Health and Wellbeing. In If not for profit, for what? And how? Liege, Belgium: EMES-SOCENT Conference Selected Papers, no. LG13-70. Retrieved from http://www.iapsocent.be/sites/default/files/Hill\%200\%27Connor\%20ECSP-LG13-70.pdf

Keen, S. (2011). Debunking Economics - Revised and Expanded Edition: The Naked Emperor Dethroned? (Second Revised \& enlarged.). London: Zed Books.

Kelly, M. P., McDaid, D., Ludbrook, A., \& Powell, J. (2005). Economic Appraisal of Public Health Interventions. Health Development Agency London. Retrieved from http://www.cawt.com/Site/11/Documents/Publications/Population\%20Health/Econo mics\%20of\%20Health\%20Improvement/Economic_appraisal_of_public_health_interve ntions.pdf

Kerlin, J. A. (2006). Social Enterprise in the United States and Europe: Understanding and Learning from the Differences. VOLUNTAS: International Journal of Voluntary and Nonprofit Organizations, 17(3), 247-263.

Kerlin, J. A. (Ed.). (2009). Social Enterprise: A Global Comparison. Lebanon, NH: University Press of New England.

Kerlin, J. A. (2013). Defining Social Enterprise Across Different Contexts: A Conceptual Framework Based on Institutional Factors. Nonprofit and Voluntary Sector Quarterly, 42(1), 84-108. 
Khatibi, F. ., \& Indira, M. (2011). Empowerment of Women through Self Help Groupd and Environmental Management: Experiences of NGOsin Karnataka State, India. Journal of Human Ecology, 34(1), 29- 40.

Marmot, M. G. (2010). Fair Society, Healthy Lives: The Marmot Review - Strategic Review of Health Inequalities in England Post-2010. London: The Marmot Review.

Marmot, M. G., \& Wilkinson, R. G. (2006). Social Determinants of Health. Oxford: Oxford University Press.

Mayo, E., Sattar, D., Conaty, P., \& McGeehan, S. (2001). Homeopathic Finance - Equitable Capital for Social Enterprises. London: New Economics Foundation. Retrieved from http://i-re.org/bdf/docs/homeopathic_finance_final_31_may_2001.pdf

Mays, N., Mulligan, J., \& Goodwin, N. (2000). The British Quasi-Market in Health Care: A Balance Sheet of the Evidence. Journal of Health Services Research \& Policy, 5(1), 49-58.

McCartney, G., Collins, C., \& Mackenzie, M. (2013). What (or Who) Causes Health Inequalities: Theories, Evidence and Implications? Health Policy, 113(3), 221-227.

McHugh, N., Gillespie, M., Loew, J., \& Donaldson, C. (2014). First Steps towards Self-Employment - Microcredit for Enterprise in Scotland. Scottish Affairs, 23(2), 169-191. doi:10.3366/scot.2014.0016

McKinlay, J. (1974). A Case for Refocusing Upstream: The Political Economy of Illness (Proceedings of American Heart Association Conference on Applying Behavioural Science to Cardiovascular Risk.). Seattle, WA: American Heart Association.

McKinlay, J. (1979). A Case for Refocusing Upstream: The Political Economy of Illness. In J. Gartley (Ed.), Patients, Physicians and Illness: A Sourcebook in Behavioral Science and Health (pp. 9-25). New York: Free Press. 
Mendell, M. (2009). Three Pillars of the Social Economy. In A. Amin (Ed.), The Social Economy: International Perspectives on Economic Solidarity (pp. 176-207). London; New York: Zed Books.

Millar, R. (2012). Social Enterprise in Health Organisation and Management: Hybridity or Homogeneity. Journal of Health Organization and Management, 26(2), 143-148.

Milton, B., Attree, P., French, B., Povall, S., Whitehead, M., \& Popay, J. (2011). The Impact of Community Engagement on Health and Social Outcomes: A Systematic Review. Community Development Journal, 47(3), 316-334.

Mohindra, K. S., Haddad, S., \& Narayana, D. (2008). Can Microcredit Help Improve the Health of Poor Women? Some Findings from a Cross-Sectional Study in Kerala, India. International Journal for Equity in Health, 7(1), 2.

Mooney, G. H. (2012). The Health of Nations: Towards a New Political Economy. London: Zed Books.

Nicholls, A., \& Young, R. (2008). Preface. In A. Nicholls (Ed.), Social Entrepreneurship: New Models of Sustainable Social Change. Oxford: Oxford University Press.

Nussbaum, M. C. (2011). Creating Capabilities: The Human Development Approach. Cambridge, Mass.: Belknap Press of Harvard University Press.

Nussbaum, M., \& Sen, A. (Eds.). (1993). The Quality of Life. Oxford: Oxford University Press.

O’Mara-Eves, A., Brunton, G., McDaid, D., Oliver, S., Kavanagh, J., Jamal, F., ... Thomas, J. (2013). Community Engagement to Reduce Inequalities in Health: A Systematic Review, MetaAnalysis and Economic Analysis. Public Health Research, 1(4), 1-548.

Pearce, J. (2003). Social Enterprise in Anytown. London: Calouste Gulbenkian Foundation.

Pestoff, V. (2013). Collective Action and the Sustainability of Co-Production. Public Management Review, 1-19. 
Phelan, J. C., Link, B. G., Diez-Roux, A., Kawachi, I., \& Levin, B. (2004). "Fundamental Causes" of Social Inequalities in Mortality: A Test of the Theory. Journal of Health and Social Behavior, 45(3), 265-285.

Rieto-Carrón, M., Lund-Thomsen, P., Chan, A., Muro, A., \& Bhushan, C. (2006). Critical Perspectives on CSR and Development: What We Know, What We Don't Know, and What We Need to Know. International Affairs, 82(5), 977-987.

Roy, M. J., Donaldson, C., Baker, R., \& Kay, A. (2013). Social Enterprise: New Pathways to Health and Well-being? Journal of Public Health Policy, 34(1), 55-68.

Roy, M. J., Donaldson, C., Baker, R., \& Kerr, S. (2014). The Potential of Social Enterprise to Enhance Health and Well-being: A Model and Systematic Review. Social Science \& Medicine. doi:10.1016/j.socscimed.2014.07.031

Roy, M. J., McHugh, N., \& Hill O’Connor, C. (2014). Social Innovation: Worklessness, Welfare and Well-being. Social Policy and Society, 13(3), 457-467.

Roy, M. J., McHugh, N., Huckfield, L., Kay, A., \& Donaldson, C. (2014). “The Most Supportive Environment in the World"? Tracing the Development of an Institutional "Ecosystem" for Social Enterprise. Voluntas: International Journal of Voluntary and Nonprofit Organizations. doi:10.1007/s11266-014-9459-9

Sen, A. (1985). Commodities and Capabilities. New York: Oxford University Press.

Sen, A. (2008). The Economics of Happiness and Capability. In L. Bruni, F. Comim, \& M. Pugno (Eds.), Capabilities and Happiness (pp. 16-27). Oxford; New York: Oxford University Press.

SENSCOT. (2010). The Five Criteria. Edinburgh: SENSCOT. Retrieved from http://www.senscot.net/docs/scottishcriteriajune10wb.pdf 
SENSCOT. (2013). The Code: Voluntary Code of Practice for Social Enterprise in Scotland. Edinburgh: SENSCOT. Retrieved from www.se-code.net/VoluntaryCodeofPractice.pdf

Shaw, M., Dorling, D., \& Smith, G. D. (2005). Poverty, Social Exclusion and Minorities. In M. Marmot \& R. Wilkinson (Eds.), Social Determinants of Health. Oxford: Oxford University Press.

Spear, R. (2001). United Kingdom: A Wide Range of Social Enterprises. In C. Borzaga \& J. Defourny (Eds.), The Emergence of Social Enterprise (pp. 252-269). London: Routledge.

Stiglitz, J. E. (1990). Peer Monitoring and Credit Markets. The World Bank Economic Review, 4(3), $351-366$.

Stiglitz, J. E. (2010, August 19). Needed: A New Economic Paradigm. Financial Times. Retrieved from http://www.ft.com/cms/s/0/d5108f90-abc2-11df-9f0200144feabdc0.html\#axzz2RZKPUNJ9

Swain, R. B., \& Wallentin, F. Y. (2009). Does Microfinance Empower Women? Evidence from Self-Help Groups in India. International Review of Applied Economics, 23(5), 541-556. doi:10.1080/02692170903007540

Szreter, S., \& Woolcock, M. (2004). Health by Association? Social Capital, Social Theory, and the Political Economy of Public Health. International Journal of Epidemiology, 33(4), 650667. doi:10.1093/ije/dyh013

Teasdale, S. (2011). What's in a Name? Making Sense of Social Enterprise Discourses. Public Policy and Administration, 27(2), 99-119.

Tesoriero, F. (2006). Strengthening Communities Through Women's Self Help Groups in South India. Community Development Journal, 41(3), 321-333.

Uphoff, E. P., Pickett, K. E., Cabieses, B., Small, N., \& Wright, J. (2013). A Systematic Review of the Relationships Between Social Capital and Socioeconomic Inequalities in Health: A 
Contribution to Understanding the Psychosocial Pathway of Health Inequalities. International Journal for Equity in Health, 12(1), 54. doi:10.1186/1475-9276-12-54

Wallerstein, N. (2006). What Is the Evidence on Effectiveness of Empowerment to Improve Health? Copenhagen: World Health Organisation Regional Office for Europe. Retrieved from http://www.euro.who.int/_data/assets/pdf_file/0010/74656/E88086.pdf

Weber, H. (2004). The "New Economy" and Social Risk: Banking on the Poor? Review of International Political Economy, 11(2).

Whitehead, M., Dahlgren, G., \& Gilson, L. (2001). Developing the Policy Response to Inequities in Health: A Global Perspective. In T. Evans, M. Whitehead, F. Diderichsen, A. Bhuiya, \& M. Wirth (Eds.), Challenging Inequities in Health: from Ethics to Action (pp. 309 - 323). Oxford: Oxford University Press.

Young, D. R., \& Lecy, J. D. (2013). Defining the Universe of Social Enterprise: Competing Metaphors. VOLUNTAS: International Journal of Voluntary and Nonprofit Organizations. doi:10.1007/s11266-013-9396-z

Yunus, M. (1998). Poverty Alleviation: Is Economics Any Help? Lessons from the Grameen Bank Experience. Journal of International Affairs, 52(1), 47-65.

Yunus, M. (2009a). Creating a World Without Poverty: Social Business and the Future of Capitalism. Philadelphia: Public Affairs.

Yunus, M. (2009b). The 7 Principles of Social Business. Retrieved April 26, 2013, from http://www.grameencreativelab.com/a-concept-to-eradicate-poverty/7principles.html 